Agnieszka Radek $\star$

\title{
An Overview of Micro- and Macroprudential Policy Tools in the EU in the Times of the COVID-19 Pandemic Economic Shock
}

\begin{abstract}
The financial crisis from 2008 and the following Eurozone crisis from 2012 created an incentive to establish a system of financial supervision at the European Union ("EU") level, due to the fact that the policy tool commonly used turned out to be ineffective. With regards to banking supervision, the package of legislations: "CRR/CRD" and "BRRD" has been adopted as a response to financial system shortcomings, in order to make it more resilient and harmonised. One of the challenges was to take control of the so-called: "too big to fail" financial institutions, therefore next to macroprudential supervision, microprudential policy pools were introduced. This constituted the phenomena of the shift from regulationbased supervision to risk-based supervision with the aim of reducing the systemic risk in each and every EU Member State and, in turn, prevent possible future crises. In this paper, those methods will be gathered, presented, and discussed in the light of the current COVID-19 pandemic crisis.
\end{abstract}

Keywords: European Union, Banking Union, Microprudential, Macroprudential, COVID-19, Crisis

\section{Introduction}

In the theory of macroeconomics it is assumed that, as the economy has been fluctuating, either due to the demand or supply shocks, the usual response of the states and governors was to use monetary and fiscal policy

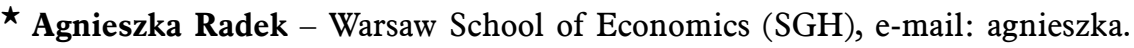
radek91@gmail.com, ORCID: 0000-0002-8284-5052. 
tools. The aim was to deal with the impact of those shocks in order to diminish potentially severe consequences and ease a smooth comeback to market equilibrium. ${ }^{1}$ During the latest global financial crisis, which started at the end of 2007, we discovered that the monetary policy might not be effective if the financial system is impaired. This crisis is said to be the deepest and most severe economic downturn since the infamous Great Depression of the 1930s. Although the crisis began in the United States, it spread around the world quickly and soon became a global issue. It occurred because all markets are now highly interrelated in such a hectic and deeply globalised economy. In other words, the global economy is highly internationalised, which implies that not only well-developed, but also developing countries were affected by the crisis and therefore suffered. After the crisis spread to Europe, it hit the economies of EU countries. In response, the European Central Bank ("ECB"), an EU institution responsible for the monetary policy of those EU Member States which have adopted the euro, implemented a very ambitious monetary policy, intervening heavily in the Eurozone's economies. The expansionary monetary policy stance may not be, however, expected to last forever. ${ }^{2}$ This policy has generated substantial risks to both the ECB's primary task and its independence. Consequently, it appeared not to be enough given that a policy trade-off between stabilising inflation and output gap emerged. ${ }^{3}$ It seems that the monetary policy would not be effective if the financial system is impaired, which led to the need for a fundamental evaluation of the ECB's monetary policy strategy. ${ }^{4}$

\section{Macro- and Microprudential Policy in the EU}

The global financial crisis highlighted the need for a macroprudential policy framework. In 2009 the European Commission, which is the EU's politically independent executive body, commissioned a high-level group chaired by Jacques de Larosière (ex-director of the International Monetary Fund). The group's task was to prepare a proposal to strengthen financial supervision with the aim of better protecting citizens and restoring their trust in the financial system. It has to be emphasised

1 A. Benassy-Quere, et al., Economic Policy Theory and Practice, second edition, Oxford 2019, p. 227.

2 The European Economic Advisory Group, Report on the European Economy, Institute for Economic Research, 2010, p. 28.

3 A. Silvo, The Interaction of Monetary and Macroprudential Policies, "Journal of Money. Credit and Banking”, no. 51(4)/2019, DOI: https://10.1111/jmcb.12524.

${ }^{4}$ S. Eijffinger, L. Hoogduin, ECB: Quo Vadis?, "Intereconomics", no. 53(3)/2018, pp. 170-173, DOI: https://doi.org/10.1007/s10272-018-0741-8. 
that the aim of macroprudential regulation shall not be considered as to eliminate recessions. ${ }^{5}$ Research shows that macroprudential policies are able to alleviate the impact of capital ratio on lending, in particular during a crisis, and may have certain implications for policymakers in the area of implementation of commonly recognised standards targeted at the reduction of borrower risk-taking. ${ }^{6}$ In the EU, a number of important steps have been taken to address this issue. The major takeaway was that supervision should be exercised on macro (overall systemic risk) and microprudential (limit the distress at individual institutions) levels. ${ }^{7}$ Macroprudential policy seeks to increase the resilience of financial system to shocks, limit the build-up of vulnerabilities over time, control the structural vulnerabilities that could rise from inter-linkages and control the "too big to fail" institutions. ${ }^{8}$ Such a framework would equip the authorities responsible for overseeing the financial system with appropriate mandates, analytical tools, and instruments to address systemic risk. The intermediate targets of macroprudential policy can be related to externalities that arise along dimensions of systemic risk, ${ }^{9}$ however, it has to the emphasised that this idea is not particularly new. When the German economy suffered during Great Depression and had to fight severe inflation and depression, there was a dedicated organisation established, namely the Bank for International Settlements whose aim was to deal with systemic risk. On the EU level, the definition might be derived from Regulation(EU) No 1092/2010. ${ }^{10}$ According to the mentioned Regulation, "systemic risk" connotes a risk of disruption in the financial system with the potential to have serious negative consequences for the real economy of the EU as a whole, or of one or more of its Member States

${ }^{5}$ D. Aikman, J. Bridges, A. Kashyap, C. Siegert, Would Macroprudential Regulation Have Prevented the Last Crisis?, "Journal of Economic Perspectives", no. 33(1)/2019, pp. 107-113, DOI: https://doi.org/10.1257/jep.33.1.107.

${ }^{6}$ M. Olszak, S. Roszkowska, I. Kowalska, Do macroprudential policy instruments reduce the procyclical impact of capital ratio on bank lending? Cross-country evidence, "Baltic Journal of Economics", no. 19(1)/2019, pp. 1-38, DOI: https://doi.org/10.1080/14060 99X.2018.1547565.

7 A. Alin-Marius, F. Melnic, S. Nistor, Effects of Macroprudential Policy on Systemic Risk and Bank Risk Taking, "Finance a úvěr-Czech Journal of Economics and Finance", no. 68(3)/2018.

8 Ibidem.

9 G. Galati, R. Moessner, What Do We Know About the Effects of Macroprudential Policy?, "Economica", no. 85(340)/2018, pp. 735-770, DOI: http://10.1111/ecca.12229.

${ }_{10}$ Regulation (EU) No 1092/2010 of the European Parliament and of the Council of 24 November 2010 on European Union macro-prudential oversight of the financial system and establishing a European Systemic Risk Board, Brussels 30/12/2019. 
and for the functioning of the internal market. The quoted definition shall address any risk of disruption in financial services which would be caused by an impairment of all or parts of the financial system and would have the potential to have serious negative consequences for the internal market and the real economy. It is worth mentioning that all types of financial intermediaries, markets, and infrastructure may be potentially systemically important to a degree (even those falling under the definition of shadow banking). Systemic risk shall be also understood as the risk that some market participants could be unable to meet their obligations due to the insolvency of the another market participant. ${ }^{11}$ As a result of a chain reaction, considerable solvency problems can arise for all of the interlinked market participants. It could threaten the stability of the entire financial system. The aim of macroprudential supervision is to identify, evaluate, and mitigate risk to the financial system and is how it serves its purpose. Macroprudential monitoring also refers to the activities of the relevant supervisory authorities at national and supranational levels in case a crisis were to be inevitable so that the financial system would not create shocks which could trigger recessions or amplify other shocks to make recessions materially worse. ${ }^{12}$ As per its definition, macroprudential supervision seeks to ensure financial stability; however, some researchers are of the opinion that there is no clear definition of financial stability. ${ }^{13}$ In other words, the objective of macroprudential policy is to use prudential means to enhance system-wide financial stability with a view to limiting macroeconomic costs from financial distress. ${ }^{14}$ For this reason, macroprudential monitoring supplements the microprudential supervision of the individual institutions that serve as economic actors in the financial system i.e., credit institutions, insurers, asset managers, shadow banks, financial market infrastructures and other financial institutions and markets. Dedicated supervisiory authorities have been established on the national and supranational level to safeguard the mandate in that regard. This mandate has the above-mentioned ECB for the Eurozone countries, whereas for instance in Poland, the statutory objective of the Polish Central Bank [pl: Narodowy Bank Polski ("NBP”)]

${ }^{11}$ F. Strauss, Soft Law als Steuerungsinstrument in der Bankenausicht, Eine Untersuchung im Völkerrecht, europäischen Unionsrecht und deutschen Verfassungsrecht am Beispiel der Basler Akkorde, Nomos, Baden-Baden 2016, p. 36, DOI: https://doi. org/10.5771/9783845271712.

12 D.D. Aikman, J. Bridges, A. Kashyap, C. Siegert, op.cit., pp. 107-113.

13 R.A. Moruțan, $A$ view of macroeconomic stability, "Annals of Faculty of Economics", no. 1(2)/2015, pp. 720-727, https://repec:ora:journl:v:1:y:2015:i:2: (access 1.04.2021).

${ }^{14}$ G. Galati, R. Moessner, op.cit., pp. 735-770. 
is to reduce or eliminate systemic risk and the macroprudential objective of the NBP is to ensure the resilience of the financial system if the systemic risk materialises. ${ }^{15}$

Among the macroprudential policy tools introduced in the EU, a number of measures shall be distinguished. ${ }^{16} \mathrm{~A}$ set of relevant capital buffers plays a major role. Under the definition of a buffer, it may be considered an additional layer of usable capital that can be drawn down when losses are incurred by an entity. Depending on the aim of the particular buffer, it may be distinguished as:

- Combined capital buffer requirement $(\mathrm{CCoB})$ - required for a credit institution to meet its own funds requirement;

- Countercyclical capital buffer requirement (CCyB) - designed to mitigate pro-cyclicality in the financial system and to build a capital buffer during periods of excessive credit growth, which is then released when a systemic risk abates;

- Structural systemic risks (SRB) - designated as a long-term noncyclical nature and shall be imposed on the basis of the financial system's structural risks and any potential vulnerabilities affecting the financial system;

The required percentage of capital that needs to be held differs among buffers. Recent developments lead to common practice of imposing the buffers depending on the size of the institution. There is distinction between Global Systemically Important Financial Institutions ("G-SII") ${ }^{17}$ and Systemically Important Financial Institutions ("O-SII"). In other words, those which, from an international perspective, are considered "too big to fail" (G-SII) and i.e., those which, from a domestic perspective, are considered "too big to fail" (O-SII), whereas the assessment shall be conducted on the national level by a competent supervisiory authority. In Member States with a less significant banking market such as Poland, there is no G-SII at all.

The next category of macroprudential measures consists of the recognition measures in the area of liquidity, as well as indicators from the balance sheet analysis, such as: risk weights (RW), loss given default

15 Narodowy Bank Polski, Wskaźniki cyklu kredytowego oraź kalibracja antycyklicznego bufora kapitałowego w Polsce, 2016, https://www.nbp.pl/nadzormakroostroznosciowy/publikacje/2016.02.15_poziom_ccb.pdf (access 20.12.2020).

16 U. Kochanska, The ESRB Macroprudential $\bar{M}$ easures Database, December 2017, https://www.esrb.europa.eu/national_policy/shared/pdf/esrb_macroprudentialmeasu resdatabase_20171215_en.pdf (access 20.12.2020).

${ }_{17}$ Financial Stability Board, Global Systemically Important Financial Institutions (G-SIFIs), https://www.fsb.org/work-of-the-fsb/policy-development/addressing-sifis/ global-systemically-important-financial-institutions-g-sifis/ (access 20.04.2020). 
(LGD) floors, and limits for: loan-to-value (LTV), ${ }^{18}$ loan-to-income (LTI) or debt servicing to-income (DSTI), liquidity charges, loan-todeposit (LTD) limit, and liquidity buffers. Those measures are imposed by the supervision authority and any deviation by a particular institution constitutes a red flag.

This introduction of the above-mentioned macroprudential policy tools has generated substantial risks to both the ECB's primary task and its independence. ${ }^{19}$ Unfortunately, despite those measures, a so-called "sovereign debt crisis" emerged in Greece, Portugal, and Ireland in year $2012^{20}$ and had negative implications for the Eurozone as a whole. It became apparent that due to the close links between public budgets and the banking sector, a crisis in one Member State could easily lead to cross-border contagion and financial dislocation in other EU countries. It strengthened the need to establish a system of financial supervision at the EU level, an incentive to which had already been indicated during the first wave of consequences of the financial crisis from 2008. At that time, the European Commission presented an action plan for the banking union. Such a regulatory project for banking supervision was implemented in accordance with a so-called: Lamflaussy process. The legislation was passed to ensure the security of the European banking system by establishing a European System of Financial Supervision as of $1^{\text {st }}$ of January 2011, consisting of three supervisory authorities representing each sector of the financial market: banking, capital, and insurance. ${ }^{21}$ Subsequently, as a response to the above-mentioned "European sovereign debt crisis", the common system of financial supervision, comprising the Single Supervisory Mechanism ("SSM"), the ECB and the national competent authorities of the Eurozone countries has been established. The SSM aims to ensure the security and solidity of the European banking system and to increase financial integration and stability in Europe. The SSM plays a vital role in the new banking supervision system for Europe. The EU's Banking Union, however, still unfinished, enables the uniform application of EU banking rules in the Member States. The major legislations, of which the Banking Union consists, may be stated as follows: Regulation

18 R. Bachmann, S.K. Ruth, Systematic Monetary Policy and the Macroeconomic Effects of shifts in residential Loan-To-Value ratios, "International Economic Review", no. 61(2)/2020, DOI: https://10.1111/iere.12432.

19 S. Eijffinger, L. Hoogduin, op.cit., pp. 170-173.

20 I. Jianu, $A$ comprehensive view on the manifestations of aggregate demand and aggregate supply shocks in Greece, Ireland, Italy and Portugal, "Theoretical and Applied Economics", no. 2(607)/2016, pp. 207-224.

${ }^{21}$ M. Iwanicz-Drozdowska, Europejska sieć bezpieczeństwa finansowego. Rozwiazania pokryzysowe, "Studia BAS”, no. 1(53)/2018, pp. 7-24. 
(EU) No 575/2013 (“CRR"), ${ }^{22}$ Directive 2013/36/EU (“CRD”), ${ }^{23}$ and Directive 2014/59/EU ("BRRD”). ${ }^{24}$

Post-crisis reforms in the EU have two major objectives, the main one is to reduce the probability of future crises and another is to improve the crisis resolution mechanism in case of a crisis. ${ }^{25}$ Some scholars suggest that after the implementation of reforms, the greatest challenge for the ECB has been to lift the inflation rate just below $2 \% .{ }^{26}$

The above-described evolution of the supervisory approach constitutes a shift from regulation based to risk-based supervision ${ }^{27}$. At the beginning, a purely regulation or compliance-based supervision approach was preferred. The compliance-based approach aims at allocating regulatory resources equally across all regulated entities in a particular Member-State. In other words, there is no distinction of risk distribution regardless of the size of the entities. As a consequence, the "too big to fail" institutions are treated as equally as all the others, including small cooperative banks. With the development of the supervisory approach, risk-based supervision was considered more effective. Risk-based supervision requires regulators, both on national and supranational levels, to assess the risk of individual entities falling under the scope of supervision in order to efficiently reduce the systemic risk to the wider economy. Setting an add-on is usually performed by supervisory judgement on a case-by-

${ }^{22}$ Regulation (EU) No 575/2013 of the European Parliament and of the Council of 26 June 2013 on prudential requirements for credit institutions and investment firms and amending Regulation (EU) No 648/2012 (Text with EEA relevance)Text with EEA relevance, Brussels 27.06.2020.

${ }^{23}$ Dyrektywa Parlamentu Europejskiego i Rady 2013/36/UE z dnia 26 czerwca 2013 r. w sprawie warunków dopuszczenia instytucji kredytowych do działalności oraz nadzoru ostrożnościowego nad instytucjami kredytowymi i firmami inwestycyjnymi, zmieniająca dyrektywę 2002/87/WE i uchylająca dyrektywy 2006/48/WE oraz 2006/49/WE. Tekst mający znaczenie dla EOG, Brussels 29/12/2020.

${ }^{24}$ Directive 2014/59/EU of the European Parliament and of the Council of 15 May 2014 establishing a framework for the recovery and resolution of credit institutions and investment firms and amending Council Directive 82/891/EEC, and Directives 2001/24/EC, 2002/47/EC, 2004/25/EC, 2005/56/EC, 2007/36/EC, 2011/35/EU, 2012/30/ EU and 2013/36/EU, and Regulations (EU) No 1093/2010 and (EU) No 648/2012, of the European Parliament and of the Council, Text with EEA relevance, Brussels 07.01.2020.

${ }^{25}$ C.M. Bunch, B. Weigert, Macroprudential policy in a currency union, "Review of World Economics”, 155(1)/2019, pp. 23-33, DOI: https://doi.org/10.1007/s10290-018 -0332-6.

${ }^{26}$ B.S. Pîra, Eurozone And The Low Inflation Risk, Sea - Practical Application Of Science, "Romanian Foundation For Business Intelligence", no. 8/2015, pp. 149-153.

${ }_{27}$ T. Randle, Risk Based Supervision, World Bank, 2009, DOI: https://doi. $\operatorname{org} / 10.1596 / 27499$. 
case basis. Some researchers confirm that in pre-crisis times we had to deal with internal synchronisation between the financial and economic crisis, while the post-crisis times are characterised by external international synchronisation, which may directly translate into the ease of use of macroeconomic tools. ${ }^{28}$

As the process of completing the Banking Union is still unfinished and is constantly developing, and in response to financial system shortcomings observed, the European Commission, after getting the opinion of the ECB, proposed in 2019 amendments to the CRR/CRD and BRRD, with the aim of boosting resilience and stability. Among others introduced, one may indicate the following requirements imposed on credit institutions:

- Leverage ratio ("LCR"), which allows for the assessment of institutions' exposure to the risk of excessive leverage (going concern approach);

- Total loss absorption capacity (“TLAC”) - a new requirement, designed for global, systemically important banks to ensure that they would have enough equity and bail-in debt to pass losses to investors and minimise the risk of a government bailout (the gone concern approach);

- Increased requirement on minimum own funds and eligible liabilities requirement ("MREL") imposed in order to avoid institutions structuring their liabilities in a way that impedes the effectiveness of the bail in or other resolution tools, and to avoid the risk of contagion or a bank run (gone concern approach); $;^{29}$

- Altered Pillar 2 Requirement ("P2R") that is a legally binding capital requirement, which applies in addition to minimum capital requirement (Pillar 1) and covers risks which are underestimated or not covered by this requirement (going concern approach);

- Pillar 2 Guidance ("P2G"), which shall be understood similarly to $\mathrm{P} 2 \mathrm{R}$, however, it is not legally binding (going concern approach); and

- Net stable funding ratio ("NSFR") - a new ratio of a long-term liquidity (going concern approach).

28 Ł. Kurowski, K. Rogowicz, Are business and credit cycles synchronised internally or externally?, "Economic Modelling”, no. 74/2018, pp. 124-114, DOI: https://doi. org/10.1016/j.econmod.2018.05.009.

29 European Banking Authority (EBA), FINAL Draft Regulatory Technical Standards on criteria for determining the minimum requirement for own funds and eligible liabilities under Directive 2014/59/EU, EBA/RTS/2015/05, 2015. 
Some researchers are of the opinion that the recent financial crisis highlighted that any policies, already implemented in the field of macroeconomic stability prior to the year 2008, were not enough to foresee the upcoming crisis and prevent its consequences. Therefore, those researchers emphasise the need for a re-assessment of macroeconomic policies in order to find adequate measures which can be taken during economic growth and could, in turn, limit the effects of upcoming future crises and to ensure adequate reserves for a possible default scenario ${ }^{30}$. Nevertheless, research shows that actions taken on the macroprudential level could have significantly ameliorated the macroeconomic fall-out. ${ }^{31}$

\section{COVID-19 - 2020 Shock}

The above-described set up did not have to wait long for a trial in a real-life crisis scenario. While some researchers had already confirmed the positive impact of macro-prudential tools, ${ }^{32}$ the World Health Organization (WHO) announced on $10^{\text {th }}$ of March 2020 the outbreak of COVID-19 as a global pandemic. The mysterious and potentially extremely contagious virus, which started in China, had quickly spread to Italy and other EU countries. In order to maximise the probability of containment, governors of EU Member States decided to impose strict containment measures such as quarantines and "lockdowns". On the top of that, it was accompanied by great degrees of uncertainty and implied a significant negative shock to the aggregate demand and supply market of each of the EU Member States, and consequently potentially turning into a severe crisis in the long term. Both the demand and the supply side of the Member States' economies' have been affected. The supply side had significant, negative implications for demand, especially affecting certain sectors disproportionately such as: tourism, transport, and recreational and cultural services. On the other hand, a drop in oil prices had also an impact on the effects of the current crisis. ${ }^{33}$

The initial projections for the implications of the COVID-19 shock on the economy such as a decline of GDP and the decline of HICP inflation could be significantly mitigated by immediate monetary policy reactions of each Member State. At glance, the level of panic highlighted that even

${ }^{30}$ R.A. Moruțan, op.cit., pp. 720-727.

${ }^{31}$ D. Aikman, J. Bridges, A. Kashyap, C. Siegert, op.cit., pp. 107-113.

32 A. Alin-Marius, F. Melnic, S. Nistor, op.cit.

33 European Central Bank (ECB), ECB staff macroeconomic projections for the euro area, March 2020. 
though EU Member States started implementing similar measures, in order to prevent the spread of the virus and the threat of unknown, the governors were focusing on the national economies rather than realising the common goal on the supranational EU level and making decisions with implications on the common market. Monetary policy is usually assigned to central banks which are the independent entities free from any possible political influence. The decisions of central banks regarding the interest rates are affecting the money supply, GDP equation and, in turn, the aggregate supply, which allows the economy to easily come back to medium run equilibrium. Poland's NBP used quantitative easing, deciding on purchasing longer-term securities from the open market in order to increase the money supply and encourage lending and investment increasing the money supply on the money market by the operations of the open market. On the other hand, there was the decision to cut the interest rate three times going to a historically low level from $1.5 \%$ to $0.1 \%$ and therefore the idea of zero interest rate or even negative interest rate in terms of the real terms has become vivid. ${ }^{34}$ It was a common occurance in well-developed economies of western EU Member States. As figures indicate, the difference in the reference interest rates between those set by the ECB and NBP has been diminishing over time. ${ }^{35}$

The credit institutions were significantly affected by the interest rate decisions. Forecasts were far from optimistic and were foreseeing possibly extraordinary declines in profit. In that regard, some researchers are examining whether the theory of Lucas - that the people make decisions based on experience from the past ${ }^{36}$ - applies to credit institutions. ${ }^{37}$ On the EU level, the institutions comprising the ESFS issued a number of statements or actions to deal with the effects of the COVID-19 crisis and mitigate its impact on the EU banking sector. It has been observed by the EU institutions that implications of the global crisis, which are said to be unprecedented, have prompted taking swift and decisive actions aimed at ensuring that credit institutions can continue to fulfil their basic role in funding the real economy and are able to support economic recovery. Therefore, on the microprudential

${ }^{34}$ F. Kwalik, Raport o stanie biznesu w czasie kryzysu epidemiologicznego: Banki pod presja ryzyka kredytowego i NBP, „Forbes”, https://www.forbes.pl/gospodarka/banki-isystem-finansowy-w-czasie-koronawirusa-raport/yx4fmlr (access 20.04.2020).

35 Z. Polanski, Stabilization Policies and Structural Developments: Poland and the Crises of 1929 and 2008, "CASE Working Papers", no. 9(133)/2016.

36 A. Benassy-Quere, B. Ceure, P. Jacquet, J. Pisani-Ferry, op.cit.

37 C. Bohanon, N. Curott, The coronavirus market turmoil shows limits of monetary policy, “Indianapolis Business Journal”, 13.03.2020. 
level, the so-called CRR "quick fix" ${ }^{38}$ was published in the EU Official Journal on $26^{\text {th }}$ of June 2020 , as a part of a series of measures taken by European institutions to mitigate the impact of the COVID-19 pandemic on institutions across the Member States. The CRR "quick fix" introduced certain adjustments to the CRR, such as that which concerned supervisory reporting. The aim was to facilitate lending through a set of easing measures i.e., the preferable treatment of nonperforming portfolios by the credit institutions. ${ }^{39}$ This constitutes the evidence that the macroprudential tools with the aim to prevent from systemic risk were not enough in case of such an unexpected event. The CRR "quick fix" was accompanied by guidelines on legislative and non-legislative moratoria on loan repayments applied in the light of the COVID-19 crisis, which have been published by the EBA to enable banks to report the possible impact of the crisis on exposures under the definition of forbearance or as defaulted under distressed restructuring. ${ }^{40}$ This is especially due to the fact that even the most adverse stress scenarios introduced both by banks and supervisors were not able to forecast such an event. ${ }^{41}$ The aim of the guidelines was to address data needs and to coordinate short-term additional supervisory reporting and disclosure necessary for monitoring the implementation of the measures introduced in response to the COVID-19 crisis across the EU Member States. Recently introduced recognition measures played a role in the functioning of the credit institutions. The increased requirement on minimum own funds and eligible liabilities requirement (MREL) had an impact on the resolution planning in light of the COVID-19 pandemic. The amendments to new requirement on total loss absorption capacity (TLAC) are also worth mentioning.

38 Regulation (EU) 2020/873 of the European Parliament and of the Council of 24 June 2020 amending Regulations (EU) No 575/2013 and (EU) 2019/876 as regards certain adjustments in response to the COVID-19 pandemic, Brussels, 24 June 2020.

39 Parlament Europejski, EU/EA measures to mitigate the economic, financial and social effects of coronavirus State-of-play, https://www.europarl.europa.eu/thinktank/en/document.html?reference =IPOL_IDA(2020)645723 (access 4.06.2020).

${ }^{40}$ European Banking Authority (EBA), Guidelines on legislative and non-legislative moratoria on loan repayments applied in the light of the COVID-19 crisis, https:// eba.europa.eu/regulation-and-policy/credit-risk/guidelines-legislative-and-non-legislative-moratoria-loan-repayments-applied-light-covid-19-crisis (access 22.04.2021).

${ }^{41}$ European Systemic Risk Board (ESRB), Macro-financial scenario for the 2020 EU wide banking sector stress test, January 31 2020, https:/eba.europa.eu/sites/default/documents/files/document_library//2020\%20EU-wide $\% 20$ stress $\% 20$ test $\% 20$ -\%20Macroeconomic\%20scenario.pdf (access 22.04.2021). 
In order to boost capitalisation, credit institutions started searching for alternative solutions. Therefore, the growing popularity of hybrid financial instruments might be observed. Within the meaning of hybrid financial instruments, the instruments combining the features of debt and capital, with characteristics of optionality shall be understood. Those instruments have been granted based on the CRR and are known as Additional Tier 1 hybrid financial instruments (AT1)..$^{42}$ One can model them without any restrictions and is free to add debt or capital attributes, however, complexity and the existence of sources of risk in the forms of market risk, default risk, different levels of equity and interest rate convexity, etc. resulted in shortcomings of existing pricing models and as a consequence left those AT1 instruments under-priced; ${ }^{43}$ what for some looks like an equity instrument with bond-like risk could turn out to deliver a bond-like return with equity volatility. This is especially the case in times of the COVID-19 global pandemic, wherein the market conditions have shifted to the most severe stress scenarios. It could be argued that even the most adverse scenarios created by the banks failed to predict the rapid and unexpected consequences of the economic crisis arose as a post COVID-19 heavy-measure effect. The extraordinary levels of volatility recorded in financial markets since the outbreak of COVID-19 initially had a significant impact on the capital requirements for market risk for institutions given that the Value at Risk figures increased as a consequence of the observed higher volatility, and also because of the increase of the quantitative market risk multipliers. This impacts the Common Equity Tier 1 ("CET1") ratios and the capacity of the institution to continue market making activities and provide market liquidity, which in turn may adversely affect the market order. ${ }^{44}$ Moreover, an excessive increase of capital requirements for market risk would impede the objective to free up capital to support lending to the real economy. From a financialengineering point of view, those instruments may be considered as perfect tool for maximising profit, given that the typical convertible arbitrage strategy employs delta-neutral hedging, whereas a large positive gamma can make the portfolio highly profitable, especially in case of large

${ }^{42}$ M. Liberadzki, K. Liberadzki, Konstrukcja Zasady Emisji i Wycena Hybrydowych Papierów Wartościowych na Eurorynku, Warszawa 2016.

43 A. Macrina, O. Mahomed, Consistent Valuation Across Curves Using Pricing Kernels, 2018, DOI: https://doi.org/10.2139/ssrn.3102513.

${ }_{44}$ Europejski Bank Centralny, Opinion of the European Central Bank of 20 May 2020 on amendments to the Union prudential framework in response to the COVID-19 pandemic (CON/2020/16) 2020/C 180/04, https://eur-lex.europa.eu/legal-content/PL/ $\mathrm{TXT} / \mathrm{PDF} /$ ?uri $=\mathrm{CELEX}: 52020 \mathrm{AB} 0016 \&$ from $=\mathrm{EN}$ (access 22.04.2021). 
movements in the underlying stock price. ${ }^{45}$ The excessive increase in capital requirements for market risk would hamper the goal of freeing up capital to support lending and could lead to a "credit crunch". ${ }^{46}$ The European Parliament decided not to adopt general measures to impose mandatory AT1 coupon restrictions for institutions that benefit from relief and capital conservation measures and not to give new powers to regulators to apply temporary suspensions of distributions to holders of AT1 coupons. ${ }^{47}$ Nevertheless, this has not been unified among the EU Member States.

Regarding the open market operations on the EU level, the idea of the so-called "Coronabond" was floated while discussing the possible solutions to deal with the effects of the crisis. ${ }^{48}$ The main aim of this idea is to rescue the worst-impacted countries such as Italy or Spain, where the economies are mostly based on tourism as one of the economy sectors severely hit. The idea per se is not a new one. The idea was previously raised by the European Commission as a proposed response to the European sovereign debt crisis as a possible solution. The idea, however, did not meet with the enthusiasm of Northern EU countries, such as Germany.

\section{Conclusions}

The aim of this paper was to gather, describe, present, and discuss the development of the supervision policy tools with regard to the macroprudential policy tools in the light of the COVID-19 pandemic shock. The full impact of the COVID-19 shock is very difficult to assess as the consequences are yet to come; the current epidemiological situation is far from stable. Financing conditions are expected to remain highly accommodative and the ECB's monetary policy measures will continue to be transmitted to the economy. ${ }^{49}$

45 C.W. Chang, J.S.K. Chang, Y. Feng, Pricing Options with Physically Based Exercise and Random Maturity; "Journal of Insurance Issues", no. 43(1)/2020, pp. 59-78.

${ }^{46}$ R.A. Werner, Toward a new research programme on banking and the economy - Implications of the Quantitative Theory of Credit for the prevention and resolution of banking and debt crisis, "International Review of Financial Analysis", no. 25/2012, pp. 1-17.

47 https://www.europarl.europa.eu/news/en/press-room/20200615IPR81234/covid-19 -easing-rules-to-encourage-banks-to-lend-to-companies-and-households (access 30.06.2020).

48 N. Yoshino, H. Miyamoto, M.Z. Mumtaz, How Monetary E Fiscal Policy Can Work Against Coronavirus Shock: Proposal for the Issue of Corona Bonds, Japan SPOTLIGHT, May/June 2020.

49 European Central Bank (ECB): ECB staff macroeconomic projections for the euro area, March 2020. 
The floor has been open for discussion as to whether the lessons from 2008's crisis have been learned and the test has been passed or whether there is still room for improvement. Even in the worst-case scenarios, nobody expected that the announcement of the COVID-19 global pandemic and the resultant lockdown would became a huge "real life test" for all those methods. Risk-based supervision has been challenged resulting in insufficient adverse scenarios. Undoubtedly, it may be observed that, contrary to the previous global crisis, the response methods of the prudential policy mechanisms were introduced on the supranational level by the relevant EU institutions. With regards to the banking supervision, a so-called "quick fix" has been adopted to the legislation as an immediate response with the aim of making the financial system more resilient and stable. As a consequence of introduced moratoria, credit institutions were enabled to collect information on the real effects of their financial condition. In addition, it allowed for reporting on the possible impact of a crisis on exposures under the existing definition of default or default under emergency restructuring (as defined in Article 178 (3) (d) of the CRR). The phenomenon of a credit crunch has not been observed yet, however, the lowering the interest rates would have implications in the long term.

Taking the abovementioned into account is important in order to allow effective monitoring of the effects of the COVID-19 pandemic and the application of response measures. This is especially the case, taking into account that the majority of the possible outcomes is just a forecast, whereas the development of the COVID-19 pandemic crisis is too unpredictable to allow for a decent and reliable conclusion. Therefore, this topic deserves to be further examined in the upcoming future.

\section{References}

Aikman D., et al., Would Macroprudential Regulation Have Prevented the Last Crisis?, "Journal of Economic Perspectives", no. 33(1)/2019, DOI: https://doi.org/10.1257/jep.33.1.107.

Alin-Marius A., Melnic F., Nistor S., Effects of Macroprudential Policy on Systemic Risk and Bank Risk Taking, "Finance a úvěr-Czech Journal of Economics and Finance", no. 68(3)/2018.

Bachmann R., Ruth S.K., Systematic Monetary Policy and the Macroeconomic Effects of shifts in residentialLoan-To-Valueratios, "International Economic Review", no. 61(2)/2020, DOI: https://10.1111/iere.12432.

Benassy-Quere A., et al., Economic Policy Theory and Practice, second edition, Oxford University Press, Oxford 2019. 
Bohanon C., Curott N., The coronavirus market turmoil shows limits of monetary policy, "Indianapolis Business Journal”, 13.03.2020.

Bunch C.M., Weigert B., Macroprudential policy in a currency union, "Review of World Economics", no. 155/2018, DOI: https://doi.org/10.1007/ s10290-018-0332-6.

Chang C.W., Chang J.S.K., Feng Y., Pricing Options with Physically Based Exercise and Random Maturity, "Journal of Insurance", no. 43(1)/2020.

Directive 2013/36/EU of the European Parliament and of the Council of 26 June 2013 on access to the activity of credit institutions and the prudential supervision of credit institutions and investment firms, amending Directive 2002/87/EC and repealing Directives 2006/48/EC and 2006/49/EC (Text with EEA relevance) Text with EEA relevance, Brussels 29/12/2020.

Directive 2014/59/EU of the European Parliament and of the Council of 15 May 2014 establishing a framework for the recovery and resolution of credit institutions and investment firms and amending Council Directive 82/891/EEC, and Directives 2001/24/EC, 2002/47/ EC, 2004/25/EC, 2005/56/EC, 2007/36/EC, 2011/35/EU, 2012/30/EU and 2013/36/EU, and Regulations (EU) No 1093/2010 and (EU) No 648/2012, of the European Parliament and of the Council (Text with EEA relevance)Text with EEA relevance, Brussels 07.01.2020.

Eijffinger S., Hoogduin L., ECB: Quo Vadis?, "Intereconomics", no. 53(3)/2018, DOI: https://doi.org/10.1007/s10272-018-0741-8.

European Banking Authority (EBA), FINAL Draft Regulatory Technical Standards on criteria for determining the minimum requirement for own funds and eligible liabilities under Directive 2014/59/EU, EBA/ RTS/2015/05, 2015.

European Banking Authority (EBA), Guidelines on legislative and non-legislative moratoria on loan repayments applied in the light of the COVID-19 crisis, https://eba.europa.eu/regulation-and-policy/ credit-risk/guidelines-legislative-and-non-legislative-moratoria-loanrepayments-applied-light-covid-19-crisis, (access 22.04.2021).

European Central Bank (ECB), Opinion of the European Central Bank of 20 May 2020 on amendments to the Union prudential framework in response to the COVID-19 pandemic (CON/2020/16) 2020/C 180/04, https://eur-lex.europa.eu/legal-content/PL/TXT/PDF/?uri=CELEX: 52020AB0016\&from $=\mathrm{EN}$ (access 22.04.2021).

European Central Bank (ECB): ECB staff macroeconomic projections for the euro area, March 2020.

European Systemic Risk Board (ESRB), Macro-financial scenario for the 2020 EU-wide banking sector stress test, January 31 2020, https://eba. europa.eu/sites/default/documents/files/document_library//2020\%20 
EU-wide\%20stress\%20test\%20-\%20Macroeconomic\%20scenario.pdf. (access 22.04.2021).

Financial Stability Board, Global Systemically Important Financial Institutions (G-SIFIs), https://www.fsb.org/work-of-the-fsb/policydevelopment/addressing-sifis/global-systemically-important-financial -institutions-g-sifis/ (access 20.04.2020).

Galati G., Moessner R., WhatDo We Know About the Effects of Macroprudential Policy?, "Economica", no. 85/2018, DOI: https://10.1111/ecca.12229.

Iwanicz-Drozdowska M., Europejska sieć bezpieczeństwa finansowego. Rozwiqzania pokryzysowe, "Studia BAS", no. 1(53)2018.

Jianu I., A comprehensive view on the manifestations of aggregate demand and aggregate supply shocks in Greece, Ireland, Italy and Portugal, "Theoretical and Applied Economics", no. 2(607)/2016.

Kochanska U., The ESRB Macroprudential Measures Database, December 2017, https://www.esrb.europa.eu/national_policy/shared/pdf/esrb_ma croprudentialmeasuresdatabase 20171215 en.pdf (access 20.12.20 $\overline{2} 0$ ).

Kurowski Ł., Rogowicz K., Are business and credit cycles synchronised internally or externally?, "Economic Modelling", no. 74/2018, DOI: https://doi.org/10.1016/j.econmod.2018.05.009.

Kwalik F., Raport o stanie biznesu w czasie kryzysu epidemiologicznego: Banki pod presja ryzyka kredytowego i NBP, "Forbes", https://www.forbes.pl/ gospodarka/banki-i-system-finansowy-w-czasie-koronawirusa-raport/ yx4fmlr (access 20.04.2020).

Liberadzki M., Liberadzki K., Konstrukcja Zasady Emisji $i$ Wycena Hybrydowych Papierów Wartościowych na Eurorynku, Oficyna Wolters Kluwer Business, Warszawa 2016.

Macrina A., Mahomed O., Consistent Valuation Across Curves Using Pricing Kernels, 2018, DOI: https://doi.org/10.2139/ssrn.3102513.

Moruțan R.A., $A$ view of macroeconomic stability, "Annals of Faculty of Economics", no. 1(2)/2015, https://repec:ora:journl:v:1:y:2015:i:2: (access 1.04.2021)

Narodowy Bank Polski, Wskaźniki cyklu kredytowego oraź kalibracja antycyklicznego bufora kapitałowego w Polsce, 2016, https://www.nbp. pl/nadzormakroostroznosciowy/publikacje/2016.02.15_poziom_ccb. pdf (access 20.12.2020).

Olszak M., Roszkowska S., Kowalska I., Do macroprudential policy instruments reduce the procyclical impact of capital ratio on bank lending? Cross-country evidence, "Baltic Journal of Economics", no. 19(1)/2019, DOI: https://doi.org/10.1080/1406099X.2018.1547565.

Parlament Europejski, EU/EA measures to mitigate the economic, financial and social effects of coronavirus State-of-play, https://www. 
europarl.europa.eu/thinktank/en/document.html?reference $=I P O L$ IDA(2020)645723 (access 04.06.2020).

Pîra B.S., Eurozone And The Low Inflation Risk, Sea-Practical Application Of Science, "Romanian Foundation For Business Intelligence", no. 8/2015.

Polanski Z., Stabilization Policies and Structural Developments: Poland and the Crises of 1929 and 2008, "CASE Working Papers", no. 9(133)/2016.

Randle T., Risk Based Supervision, World Bank 2009, DOI: https://doi. org/10.1596/27499.

Regulation (EU) 2020/873 of the European Parliament and of the Council of 24 June 2020 amending Regulations (EU) No 575/2013 and (EU) 2019/876 as regards certain adjustments in response to the COVID-19 pandemic, Brussels, 24 June 2020.

Regulation (EU) No 1092/2010 of the European Parliament and of the Council of 24 November 2010 on European Union macro-prudential oversight of the financial system and establishing a European Systemic Risk Board, Brussels 30/12/2019.

Regulation (EU) No 575/2013 of the European Parliament and of the Council of 26 June 2013 on prudential requirements for credit institutions and investment firms and amending Regulation (EU) No 648/2012 (Text with EEA relevance), Brussels 27.06.2020.

Silvo A., The Interaction of Monetary and Macroprudential Policies, "Journal of Money. Credit and Banking”, no. 51(4)/2019, DOI: https://10.1111/ jmcb.12524.

Strauss F., Soft Law als Steuerungsinstrument in der Bankenausicht, Eine Untersuchung im Völkerrecht, europäischen Unionsrecht und deutschen Verfassungsrecht am Beispiel der Basler Akkorde, Nomos, Baden-Baden 2016, DOI: https://doi.org/10.5771/9783845271712.

The European Economic Advisory Group, Report on the European Economy, Chapter 1, Institute for Economic Research, 2010.

Werner R.A., Toward a new research programme on banking and the economy - Implications of the Quantitative Theory of Credit for the prevention and resolution of banking and debt crisis, "International Review of Financial Analysis", no. 25/2012, DOI: https://doi.org/10.1016/j. irfa.2012.06.002.

Yoshino N., Miyamoto H., Mumtaz M.Z., How Monetary E Fiscal Policy Can Work Against Coronavirus Shock: Proposal for the Issue of Corona Bonds, Japan SPOTLIGHT, May/June 2020. 